\title{
Profile of patients with post partum hemorrhage in Dr. Soetomo Hospital, Surabaya, January 201 I - December 2013
}

\author{
Mazaya Azyati', M. Aldika Akbar', Sudarno' \\ 'Medical Doctor Program, ${ }^{2}$ Department of Obsetrics \& Gynecology, ${ }^{3}$ Department of Biochemistry, \\ Faculty of Medicine, Universitas Airlangga, Dr. Soetomo Hospital, Surabaya, Indonesia
}

\begin{abstract}
ABSTRAK
Tujuan: Mengetahui profil pasien perdarahan pasca persalinan di RSUD Dr. Soetomo Surabaya periode Januari 2011 - Desember 2013.

Bahan dan Metode: Penelitian deskriptif menggunakan data sekunder dari rekam medik tentang usia, jumlah paritas, asal, kadar $\mathrm{Hb}$, diagnosis penyebab, cara melahirkan, dan data transfusi pasien perdarahan pasca persalinan di RSUD Dr. Soetomo Surabaya periode Januari 2011 - Desember 2013.

Hasil: Hasil penelitian dengan variabel usia pasien, jumlah paritas pasien, asal pasien, kadar $\mathrm{Hb}$ pasien, diagnosis penyebab, cara melahirkan pasien, dan data transfusi pasien menunjukkan bahwa usia pasien terbanyak adalah $20-35$ tahun sebanyak 131 pasien (64,85\%), jumlah paritas pasien terbanyak adalah multipara sebanyak 134 pasien $(66,34 \%)$, asal pasien terbanyak adalah kiriman dari bidan praktik swasta (BPS) sebanyak 84 pasien $(41,58 \%)$, kadar Hb pasien terbanyak adalah $<8$ gr\% sebanyak 70 pasien $(34,65 \%)$, penyebab perdarahan pasca persalinan terbanyak adalah retensio plasenta sebanyak 63 pasien $(31,19 \%)$, cara melahirkan pasien terbanyak adalah dengan cara spontan sebanyak 164 pasien $(81,20 \%)$, dan mayoritas pasien tidak mendapatkan transfusi yaitu 131 pasien $(64,85 \%)$.

Simpulan: Mayoritas usia pasien perdarahan pasca persalinan pada usia 20 - 35 tahun, jumlah paritas dengan multipara, merupakan kiriman dari bidan praktik swasta (BPS), datang dengan kadar $\mathrm{Hb}<8$ gr \%, disebabkan karena retensio plasenta, melahirkan secara spontan, dan lebih banyak tidak mendapatkan transfusi
\end{abstract}

Kata kunci: perdarahan pasca persalinan, kehamilan, persalinan

\begin{abstract}
Objectives: To recognize profile of patients with post partum haemorrhage in Dr. Soetomo Hospital, Surabaya, from January 2011 to December 2013.

Materials and Methods: This was a descriptive study using secondary data from medical records of patients with postpartum hemorrhage at Dr. Soetomo Hospital in January 2011 - December 2013. Age, parity, origin, amount of hemoglobin, cause of postpartum hemorrhage, mode of delivery, and transfusion data patients were all recorded.

Results: Result of this study were patient's age, parity, origin, hemoglobin, cause of postpartum haemorrhage, mode of delivery, and transfusion data. From 202 cases, 131 patients $(64.85 \%)$ were 20 - 35 years old, 134 patients $(66.34 \%)$ were multipara, 84 patients $(41.58 \%)$ were from private practice midwife, 70 patients' $(34.65 \%)$ hemoglobin were $<8$ gr\%, 63 patients $(31.19 \%)$ post partum haemorrhage caused by retained placenta, 164 patients $(81.20 \%)$ labored with spontaneous way, and 131 patients $(64.85 \%)$ did not receive transfusion.

Conclusions: Most of the patients with postpartum hemorrhage were 20-35 years, multiparas, from private practice midwives, came with haemoglobin level $<8 \mathrm{gr} \%$, caused by retained placenta, delivered with spontaneous way, and did not receive transfusion.
\end{abstract}

Keywords: post partum hemorrhage, pregnancy, delivery

Correspondence: Mazaya Azyati, Medical Doctor Program, Faculty of Medicine, Universitas Airlangga, J1 Mayjen. Prof. Dr. Moestopo No. 47 Surabaya 60131, Indonesia. Phone: +6281317776820. Email: mazayaazyati@yahoo.co.id

\section{INTRODUCTION}

Indonesian Demographic and Health Survey (SDKI) result showed that the maternal mortality rate (MMR) in 2007 was 228 per 100,000 live births. The maternal mortality rate declined compared to 2002, which reached 307 per 100000 live births. The causes of maternal deaths are haemorrhage, infection, gestosis pre-eclampsia and eclampsia. Nearly 30 percent of maternal deaths in Indonesia occurred due to postpartum haemorrhage. ${ }^{1}$ Postpartum hemorrhage is a major cause of maternal mortality in developing countries and nearly a quarter of all maternal deaths globally. Forty percent of maternal deaths were due to haemorrhage associated with anemia in pregnancy. ${ }^{2}$
Postpartum hemorrhage is caused by various risk factors. Factors that influence the occurrence of postpartum hemorrhage are nutritional status of mothers, anemia in pregnancy, age, parity, interval between births, antenatal care (ANC), and the history of previous deliveries. 3 The causes of postpartum hemorrhage are left-over placenta tissues, uterine atony, retained placenta, laceration, uterine invertion, and disorders of blood clotting factors. ${ }^{4}$ The impact of postpartum hemorrhage was haemorrhagic shock, anemia and Sheehan's syndrome. As a result of the bleeding, the mother will develop shock and decreased of consciousness due to the large amount of blood loss. This causes disruption to the blood circulation 
throughout the body and can cause severe hypovolemia. If this is not treated quickly and precisely, it may cause death of the mother (Sidabutar, 2013).

This study was conducted to determine the profile of postpartum hemorrhage patients in Dr. Soetomo Hospital from January 2011 to December 2013. This research was a descriptive study using secondary data from medical records on age, parity, origin, hemoglobin level, the diagnosis of the cause, mode of delivery, and postpartum hemorrhage patient transfusion data.

\section{MATERIALS AND METHODS}

This study was a descriptive study using medical records of postpartum hemorrhage patients in Dr. Soetomo Hospital from January 2011 to December 2013. Medical records included the number of patients with postpartum hemorrhage, age distribution, parity, origin, $\mathrm{Hb}$, diagnosis, causes, mode of delivery, and postpartum hemorrhage patient transfusion data.

\section{RESULTS AND DISCUSSION}

Research data collection was performed by taking the data from the central medical record of Dr. Soetomo Hospital, particularly on patients who experienced postpartum hemorrhage. The number of patients enrolled in the inpatient of the Department of Obstetrics and Gynecology Dr. Soetomo Hospital in January 2011 - December 2013 was 349 patients. However, there were 147 patients whose medical records were not found. Secondary data that met the inclusion criteria and could be used in this study were 202 patients.

Based on age distribution, the results of this study indicated that the age of postpartum hemorrhage patients ranged from 20-35 years old, constituted the highest proportion with 131 patients $(64.85 \%)$ out of 202 subjects. Based on the total number of delivery, from 202 patient's data obtained, 134 patients were multiparas $(66.34 \%)$.

Based on patient's origin, majority of the subjects were referred from private practice midwives, comprising 84 patients $(41.58 \%)$. Based on $\mathrm{Hb}$ levels on the first day admittance, there were 70 out of 202 postpartum hemorrhage patients that had severe anemia with $\mathrm{Hb}<8$ $\mathrm{g} \%(34.65 \%)$.

\section{Age}

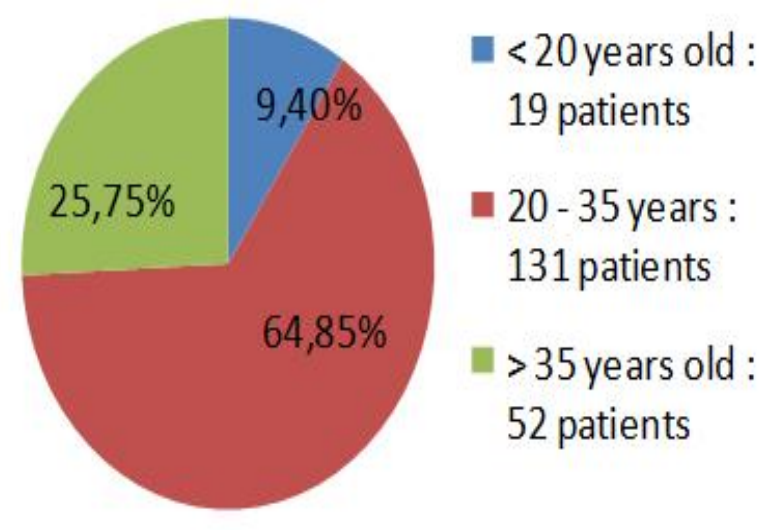

Figure1. Frequency distribution of postpartum haemorrhage $(\mathrm{PPH})$ patients based on the age in January 2011 - December 2013

\section{Parity}

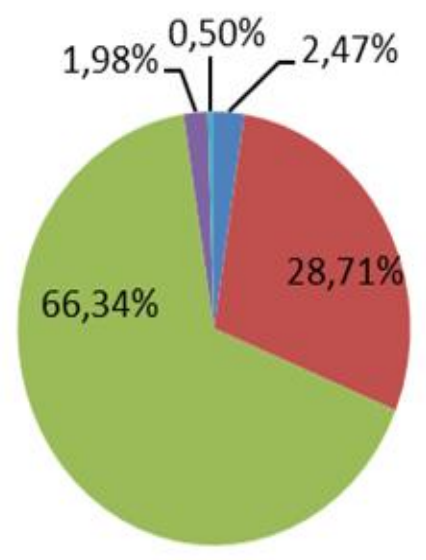

\author{
Nullipara : 5 \\ pasien \\ Primipara : 58 \\ pasien \\ Multipara : 134 \\ pasien \\ Grandemultipa \\ ra: 4 pasien \\ No data \\ :1 pasien
}

Figure 2. The frequency distribution of postpartum haemorrhage (PPH) patients based on parity in January 2011 - December 2013 


\section{Origin}

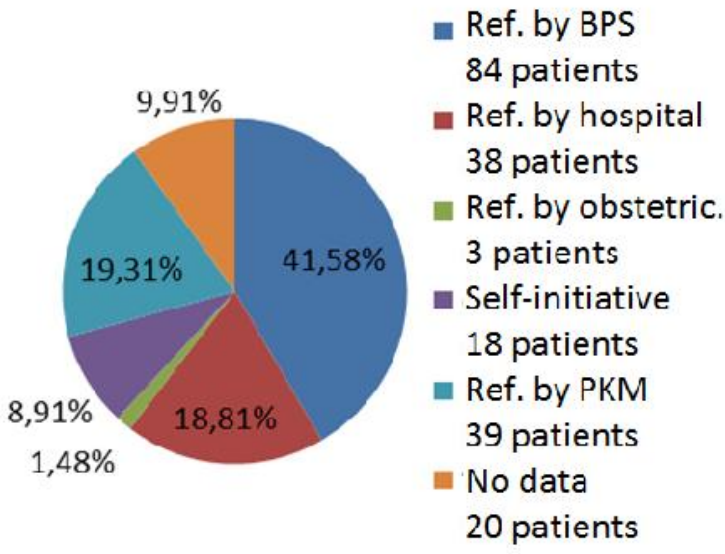

Figure 3. Frequency distribution of postpartum hemorrhage (PPH) patients based on origin in January 2011 - December 2013

\section{Hb (first day)}

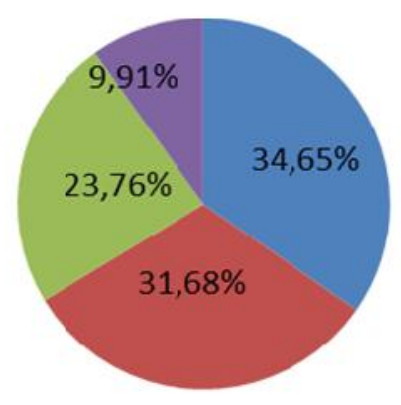

$$
\begin{aligned}
& <8 \text { gr } \%: 70 \\
& \text { patients } \\
& 8 \text { - } 10 \mathrm{gr} \%: 64 \\
& \text { patients } \\
& >10 \mathrm{gr} \%: 48 \\
& \text { patients } \\
& \text { no data : } 20 \\
& \text { patients }
\end{aligned}
$$

Figure 4. Frequency distribution of postpartum haemorrhage $(\mathrm{PPH})$ patients based on hemoglobin levels on the first day admittance to hospital in January 2011 - December 2013

Based on the results of medical records of 202 patients, diagnosis that caused postpartum hemorrhage was mostly retained placenta in 63 patients $(31.19 \%)$. Most of the patients's mode of delivery was spontaneous delivery in 164 patients $(81.2 \%)$. Based on the number of patients who obtained transfusions, from 202 patients who experienced postpartum haemorrhage, as many as $64.85 \%$ (131 patients) did not receive a transfusion.

\section{Cause of PPH}

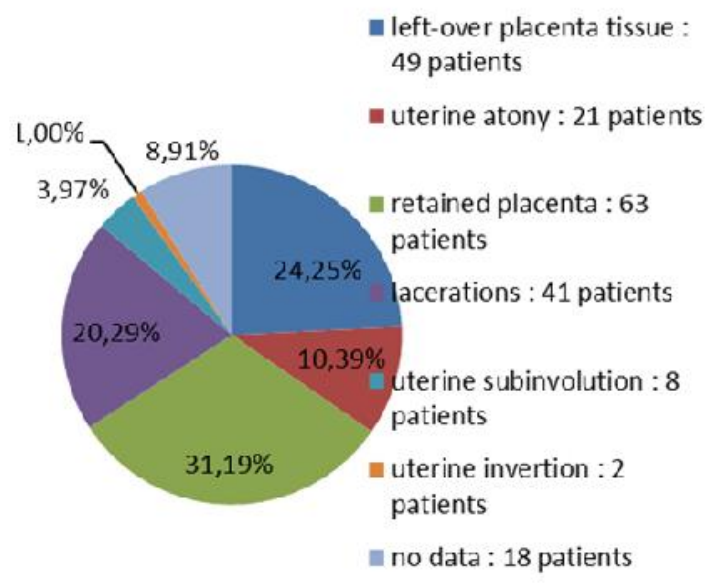

Figure 5. Frequency distribution of postpartum haemorrhage $(\mathrm{PPH})$ patients based on the diagnosis of the cause in January 2011 - December 2013.

\section{Mode of Delivery}

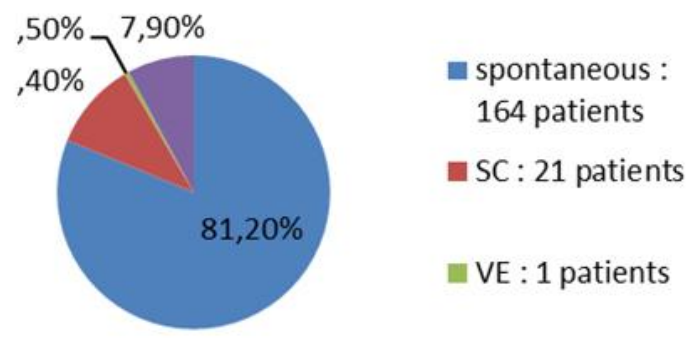

Figure 6. Frequency distribution of postpartum haemorrhage $(\mathrm{PPH})$ patients based on the mode of delivery in January 2011 December 2013

\section{Transfusion}

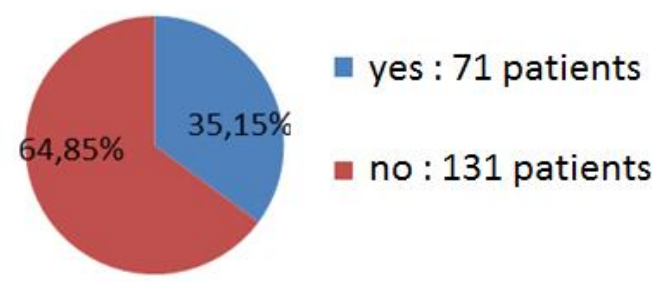

Figure 7. Frequency distribution of postpartum haemorrhage $(\mathrm{PPH})$ patients based on transfu-sion status in January 2011 December 2013. 
This research was conducted in the Department of Obstetrics and Gynecology Dr. Soetomo Hospital using medical records as data source. This research was a descriptive study and provided information on post partum hemorrhage patients' profile. On January 1st 2011 - December 31th 2013, there were 349 patients with postpartum hemorrhage based on medical records in Dr Soetomo hospitals. However, 147 patients were excluded because the records cannot be found, so that the data recorded and met the inclusion criterias were 202 datas.

Based on figure 1, the results of this study indicated that the majority of PPH patients in Dr Soetomo hospital ranged between 20-35 years $(64.85 \%)$. It was also found in Rokan Hulu Hospital, the highest age proportion of postpartum hemorrhage patients was at the age of 20-35 years old ${ }^{6 .}$ Likewise, the research in BLU Prof. Dr. RD Kandou hospital Manado showed majority of postpartum hemorrhage patients was also in the range of 2035 years old ${ }^{7}$ This can happen due to the age of a productive and mature age so many patients are pregnant and give birth at that age with the condition of the uterus is ready and mentally mature. While the proportion of $<20$ years old PPH patients in Dr Soetomo hospital were $9.40 \%$ and $>35$ years old were $25.75 \%$. In $<20$ years old women, the uterus and pelvis are not well developed and not mature enough mentally. Person aged $>35$ years old tend to bleed and have other disorders ${ }^{8}$.

From this research in Dr Soetomo Hospital there were 134 patients $(66.34 \%)$ with multiparity, primiparity in 58 patients $(28.71 \%)$, nulliparity in 5 patients $(2.47 \%)$, grande multiparity in 4 patients $(1.98 \%)$ and no data in 1 patient $(0.50 \%)$. The results of the study in Jagir public health center Surabaya revealed that mostly PPH occured in multiparity and grande multiparity women ${ }^{5}$. It is similar with the result in RS. Panti Wilasa "Dr. Cipto" Yakkum Semarang branch, most patients who suffered from PPH is the group multiparity ${ }^{9}$. Result of the research from the Obafemi Awolowo University Teaching Hospitals Complex in Nigeria also showed that the majority of PPH patients were multiparity ${ }^{10}$ The more often women experience pregnancy and childbirth the uterus is getting weaker. It can be caused by the uterus which already tend to work inefficiently so it is not elastic and reduced uterine contractions which leads to an increased risk of childbirth complications ${ }^{11 .}$

From 202 patients with postpartum haemorrhage in Dr Soetomo hospital, 84 patients were referred from private midwives $(41.58 \%), 39$ patients were referred from public health center $(19.31 \%), 38$ patients were referred from hospital (18.81\%), 18 patients came directly to RS Dr. Soetomo $(8.91 \%), 3$ patients were referred from obstetrician (1.48\%), and 20 patients had no data $(9.91 \%)$. Based on the research results in dr. Pirngadi Hospital Medan, the highest proportion of birth attendants were midwives and majority of the referrals come from clinics/midwife ${ }^{12 .}$ Maternal cases services at appropriate health facility must be obtained after getting initial treatment and conditions stabilization of in primary health care facilities. Maternal referral system may have function in reducing maternal mortality rate $^{13 .}$

Figure shows that the majority of PPH patients' had their $\mathrm{Hb}$ levels on the first day categorized as anemic. A total of 70 patients (34.65\%) suffered from severe anemia with $\mathrm{Hb}<8 \mathrm{~g} \%$ and 64 patients $(34.68 \%)$ were with mild anemia with hemoglobin levels 8-10 g\%. The remaining 48 patients $(23.76 \%)$ came with $\mathrm{Hb}>10 \mathrm{~g} \%$, while and as many as 20 patients $(9.91 \%)$ had no data. According to WHO, the mortality risk for postpartum hemorrhage is greatly increased by the presence of anemia. Blood loss of 200-250 $\mathrm{ml}$ can be fatal for patients with anemia. ${ }^{14}$ The results of the research in Rokan Hulu Hospital showed that $76.3 \%$ of the patient with hemoglobin levels $<10 \mathrm{~g} \%$ had primary PPH. ${ }^{6}$ Likewise, at William Booth Hospital Surabaya the majority of patients with PPH had severe anemia. ${ }^{15}$ Uterine atony and retained placenta are the causes of postpartum hemorrhage due to anemia in pregnancy. Anemia in pregnancy with hemoglobin levels below normal results in reduced amount of blood oxygen. If only a few of oxygen is bind, then the amount of oxygen distributed to all tissue cells will also decrease, so that muscular contraction of of the uterus is not strong. ${ }^{16}$

In this study, there were 63 patients with PPH due to retained placenta $(31.19 \%)$, followed by left-over placenta in 49 patients $(24.25 \%)$, lacerations in total of 41 patients $(20.29 \%)$, uterine atony in 21 patients $(10.39 \%)$, uterine subinvolution in 8 patients $(3.97 \%)$, uterine invertion in 2 patients $(1.00 \%)$, and no data found in 18 patients $(8.91 \%)$. This finding was similar to those taken in Rokan Hulu Hospital, with retained placenta as the most common cause of primary PPH. ${ }^{6}$ Retained placenta was also the most common cause of PPH in dr. Pirngadi Hospital, Medan, on 2004 - 2008. ${ }^{12}$ Results of a study in South America, namely in Argentina and Uruguay, from October 2003 to December 2005 also showed retained placenta as the leading cause. ${ }^{17}$ Meanwhile, in Prof. Dr. RD Kandou Hospital, from January 1, 2011 to December 31, 2011, the highest cause of PPH was retained placenta. ${ }^{7}$ In DR. H. Ansari Saleh Hospital Banjarmasin the highest cause PPP was atonic in $2011^{18 .}$ 
Postpartum hemorrhage patients in Dr Soetomo Hospital, Surabaya, mostly had spontaneous delivery with 164 patients $(81.20 \%$ ), while 21 patients had caesarian section $(10.40 \%)$. The rest of the patients had assisted delivery with vacuum extractor in only 1 patient $(0.50 \%)$ and no data of 16 patients $(7.90 \%)$. A study conducted in dr. Pirngadi Hospital, Medan, on 2004 2008 also showed that the majority of PPH patients had spontaneous labor $(96.3 \%)$ ). It was similar with a study in Prof. Dr. RD Kandou Hospital where $61.1 \%$ of patients with postpartum hemorrhage had spontaneous delivery. ${ }^{7}$ Research in Liaquat National Hospital, Karachi during the period of July 2011 - May 2012 also showed that the majority of PPH patients had spontaneous delivery. ${ }^{19}$ Estimated blood loss can be influenced by mode of delivery, which is easier to estimate blood loss in caesarian section than in vaginal deliveries. It is because the amount of blood can be measured and weighed ${ }^{20}$.

Figure 7 shows that in this study of $202 \mathrm{PPH}$ patients recorded in Dr. Soetomo Hospital, as many as 131 patients $(64.85 \%)$ did not obtain transfusion, while the remaining 71 patients $(35.15 \%)$ had transfusion of whole blood or packed red cells. Drug of choice in iron deficiency anemia is the oral iron preparations, the ferrous sulfate. The use of oral iron preparations for the treatment of iron deficiency anemia was $200 \mathrm{mg}$ per day $(2-3 \mathrm{mg} / \mathrm{kg})$. However, when oral iron preparations are ineffective due to poor iron absorption or poor tolerance of the patient, administration of parenteral iron preparations is recommended. Meanwhile, when the anemia is severe and the patient is in labor or will undergo a surgical procedure, emergency blood transfusions become the treatment of choice. ${ }^{21}$

\section{CONCLUSION}

In January 2011 - December 2013, postpartum hemorrhage patients in Dr. Soetomo Hospital were mostly in the range of $20-35$ years old $(64.85 \%)$. The majority of patients was multiparous (66.34\%) and referred from private midwives (41.85\%). Based on $\mathrm{Hb}$ levels during the first day admittance, the majority of patients had severe anemia with $\mathrm{Hb}<8 \mathrm{~g} \%$ (34.65\%). Postpartum haemorrhage was mostly caused by retained placenta $(31.19 \%)$ and spontaneous delivery $(81.20 \%)$. Majority of PPH patients did not get transfusion of packed red cells (PRC) and whole blood (WB) (64.85\%).

Improvements in data recording is needed so that all of the samples available can be examined for research purpose. Further research using more samples and additional variables is also needed to be able to more clearly illustrate the profile of postpartum hemorrhage patients in Dr. Soetomo Hospital.

\section{REFERENCES}

1. Ministry of Health. The maternal mortality rate (MMR) Childbirth. Retrieved from: http: // www. depkes.go.id/download.php?file=download/pusdati n/infodatin/infodatin-ibu.pdf.2007. Accessed 5 July 2014.

2. World Health Organization. WHO Recommendations for the prevention and treatment of postpartum haemorrhage. Retrieved from: http:// apps.who.int/iris/bitstream/10665/75411/1/9789241 548502_eng.pdf. 2012. Accessed 5 July 2014.

3. Najah SN. Several maternal characteristics that influence the incidence of postpartum hemorrhage Retrieved from: http://core.ac.uk/download/files/ 379/11705915.pdf. 2004. Accessed 7 November 2015.

4. Emilia O. Etiology and risk factors for PPH. Retrieved from: http://kesehatan-ibuanak.net/v13/ images/ETIOLOGI\%20DAN\%20FAKTOR\%20RI SIKO\%20PPH.pdf. 2011. Accessed 7 November 2015.

5. Supa $\mathrm{S}$ and Sidabutar S. The relationship between parity, birth weight, and retained placenta with the incidence of primary postpartum hemorrhage. [Online] Retrieved from: http://jurnal-griyahusada. com/awal/images/files/research\% 203.pdf. 2013. Accessed 15 November 2015.

6. Syafnelli SST and Daulay SM. Analysis of factors associated with postpartum hemorrhage primary in Rokan Hulu District Hospital in 2010. Retrieved from:http://e-journal.upp.ac.id/index.php/akbd/ article/view/142/143. 2010. Accessed 15 November 2015.

7. Londok THM, Lengkong RA, and Supaman E. Characteristics of antepartum haemorrhage and postpartum hemorrhage. Retrieved from: http://e journal.unsrat.ac.id/index.php/ebiomedik/article/do wnload/4608/4136. 2013. Accessed 15 November 2015.

8. Suryani. Relationships characteristics of maternal and antenatal care with postpartum hemorrhage in a public hospital Dr. Pirngadi Medan 2007. Retrieved from: http://repository.usu.ac.id/bitstream/1234567 89/ 6853/1/047023029.pdf. 2008. Accessed 13 January 2016.

9. Sulistiyani CN. The relationship between parity and maternal age with the incidence of postpartum hemorrhage in hospital. Panti Wilasa Dr. Cipto 
Yakkum Semarang branch in 2008. Retrieved from: http://pmb.stikestelogo-rejo.ac.id/e-journal/index. php/ilmukeperawatan/article/download/151/176. 2009. Accessed 15 November 2015.

10. Ajenifuja KO, Adepiti CA and Ogunniyi SO. Postpartum haemorrhage in a teaching hospital in Nigeria: a 5 year experience. Retrieved from: http: //www.ncbi.nlm.nih.gov/pmc/articles/PMC2895792 /pdf/AFHS1001-0071.pdf. 2010. Accessed 26 December 2015.

11. Lubis IK. The effect of parity on the primary postpartum hemorrhage in Hospital Dr. Pirngadi Medan, 2007-2010. Retrieved from: http://reposi tory.usu.ac.id/bitstream/123456789/26440/4/Chapte r\%20II.pdf. 2011. Accessed 6 July 2014.

12. Rahmi. Characteristics of postpartum hemorrhage patients who come to RSU Dr. Pirngadi Medan in 2004 - 2008. Retrieved from: http://repository.usu. ac.id/bitstream/123456789/14633/1/09E02707.pdf. 2009. Accessed 15 November 2015]

13. Hadijono RS. The management and referral of postpartum hemorrhage in efforts to reduce maternal morbidity and mortality. Retrieved from:http://kesehatan-ibuanak.net/v13/ images/Per darahan\%20postpartum\%20dan\%20sistem\%20ruju kan.pdf. 2006. Accessed 13 January 2016.

14. VD Tsu, et al. Postpartum hemorrhage in developing countries: the public health community is using the right tools? [Online] Retrieved from: http://www.ijgo.org/article/S0020-7292(04)000578/pdf. 2004. Accessed 6 July 2014.

15. Lestrina and Eny. The relationship between parity and incidence of anemia in postpartum hemorrhage in hospital william booth surabaya the period 2007 - 2012. Retrieved from: http://ejournal.stikes
williambooth.ac.id/index.php/D3BID/article/downl oad/6/5. 2012. Accessed 15 November 2015.

16. Wuryanti A. The relationship of anemia in pregnancy with postpartum hemorrhage due to uterine atony in Wonogiri District Hospital. Retrieved from: http://eprints.uns. ac.id/107/1/ 167420309201012551.pdf. 2010. Accessed 6 July 2014.

17. Sosa Claudio G, et al. Risk factors for postpartum haemorrhage in vaginal deliveries in a LatinAmerican population. Retrieved from:http://www. ncbi.nlm.nih.gov/pmc/articles/PMC2730945/pdf/ni hms125772.pdf. 2010. Accessed 26 December 2015.

18. Sari Anggrita and Sukamto. Genesis post-partum hemorrhage in BLUDs Hospital Dr. H. Ansari Saleh Banjarmasin 2011. Retrieved from: http:// akbidsarimulia.ac.id/ejurnal/downlot.php?file $=1 \% 2$ 0(1-7).pdf. 2013. Accessed 15 November 2015.

19. Edhi Mohammed, et al. Postpartum hemorrhage: causes and management. [Online] Retrieved from: http://www.ncbi.nlm.nih.gov/pmc/articles/PMC368 8110/pdf/1756-0500-6-236.pdf. 2013. Accessed 26 December 2015.

20. Holm, et al. Severe postpartum haemorrhage and mode of delivery: a retrospective cohort study. Retrieved from: http://onlinelibrary. wiley.com/doi/ 10.1111/j.1471-0528.2011.03267.x/epdf. 2012. Accessed 13 January 2016.

21. Wibowo $\mathrm{N}$ and Purba RT. Iron deficiency anemia in pregnancy. Retrieved from: http://www.dexamedica.com/sites/defjault/ files/publication_upload 070416987576001176746454DexaMediaJanMar2006.pdf. 2006. Accessed 15 November 2015. 